\title{
Penerapan Model Cooperative Learning Tipe Numbered Head Together Terhadap Hasil Belajar Pendidikan Pancasila dan Kewarganegaraan Sekolah Menengah Pertama
}

\author{
Abdul Sakban', Wahyudin ${ }^{2}$ \\ ${ }^{1}$ Pendidikan Pencasila dan Kewarganegaran, Universitas Muhammadiyah Mataram, Email: sakban.elfath@yahoo.co.id \\ ${ }^{2}$ Pendidikan Pancasila dan Kewarganegaraan, Universitas Muhammadiyah Mataram, Email: wahyudin34@gmail.com
}

\begin{abstract}
INFO ARTIKEL
Riwayat Artikel:

Diterima: $\quad$ 04-Februari-

2019

Disetujui: 24-Maret-2019
\end{abstract}

\section{Kata Kunci:}

penerapan

numbered head

together

hasil belajar

\section{A. LATAR BELAKANG}

Pendidikan adalah usaha sadar untuk menyiapkan peserta didik melalui kegiatan bimbingan, pengajaran dan pelatihan bagi peranannya di masa yang akan datang. Dalam hal ini sekolah sebagai suatu lembaga pendidikan formal secara sistematis merencanakan bermacam-macam lingkungan, yakni lingkungan

\begin{abstract}
Abstrak: Pendidikan Pancasila dan Kewarganegaraan terkadang dianggap sebagai mata pelajaran yang membosankan dan tidak menarik oleh siswa. Hal ini terjadi karena di karenakan dalam pelaksanaan kegiatan belajar mengajar guru hanya menggunakan metode klasik dan guru yang tidak dapat menyesuaikan kondisi siswa dengan materi pembelajaran yang selalu dinamis. Untuk itu, diperlukan alternatif model pembelajaran yang diterapkan untuk meningkatkan hasil belajar siswa yang memungkinkan belajar secara optimal adalah menggunakan cooperative Learning Tipe Numbered Head Together (NHT). Tujuan penelitian adalah untuk mengetahui pengaruh penerapan model Cooperative Learning Tipe Numbered Head Together (NHT) terhadap hasil belajar pendidikan pancasila dan kewarganegaraan sekolah menengah pertama. Metode penelitian menggunakan penelitian kuantitatif dengan pendekatan eksperimen. Sampel penelitian berjumlah 57 siswa, teknik pengumpulan data menggunakan observasi, tes, dan dokumentasi. Metode analisis data menggunakan rumus ttest. Hasil analisis menunjukan bahwa hasil uji t diperoleh $t_{\text {hitung }}=3,523$. Hasil uji t tersebut kemudian di konsultasikan pada $t_{\text {tabel. }}$. Dengan taraf signifikan $5 \%$ dan $\mathrm{db}=24$ diperoleh $\mathrm{t}_{\text {tabel }}$ $=1,998$ karena $t_{\text {hitung }} \geq t_{\text {tabel }}$ maka hipotesis di terima dengan demikian terdapat pengaruh penerapan model cooperative learning tipe Numbered Head Together (NHT) terhadap hasil belajar Pendidikan Pancasila dan Kewarganegaraan Sekolah Menengah Pertama. Jadi semakin tinggi menggunakan variasi model pembelajaran semakin tinggi pula dampak hasil belajar siswa.
\end{abstract}

\begin{abstract}
Pancasila and Citizenship Education is sometimes considered a dull and uninteresting subject by students. The happens because the implementation of teaching and learning activities teachers only use classical methods and teachers who cannot adjust the conditions of students with learning materials that are always dynamic. For this reason, we need an alternative learning model that is applied to improve student learning outcomes that enable optimal learning is to use cooperative learning Type Numbered Head Together (NHT). The purpose of the study was to determine the effect of the application of Cooperative Learning models Type Numbered Head Together (NHT) on the learning outcomes of Pancasila education and junior high school citizenship. The research method uses quantitative research with an experimental approach. The research sample amounted to 57 students, the technique of collecting data used observation, tests, and documentation. Data analysis method uses the t-test formula. The results of the analysis show that the results of the t-test were obtained $t=3.523$. The results of the $t$-test are then consulted on the table. With a significant level of $5 \%$ and $d b=24$ derived $t$ table $=1.998$ because $t$-count label t-table then the hypothesis is accepted thus there is an effect of applying the cooperative learning model Numbered Head Together (NHT) to the learning outcomes of Junior High School Pancasila and Citizenship Education. So the higher the variety of learning models using the more senior the impact of student learning outcomes.
\end{abstract}

pendidikan yang menyediakan berbagai kesempatan bagi peserta didik untuk melakukan berbagai kegiatan belajar maka dari itu setiap kegiatan pendidikan diarahkan kepada tercapainya pribadi yang berkembang secara ptimal sesuai dengan potensi masing-masing peserta didik. Sebagai suatu proses psikologis, pendidikan tidak dapat dipisahkan dari kegiatan belajar mengajar. Dengan demikian pendidikan adalah proses 
interaksi pendidik dan peserta didik yang memiliki tujuan tertentu[1]. Salah satu tujuan pendidika adalah menyiapkan individu untuk dapat beradaptasi atau menyesuaikan diri dan memenuhi tuntutan-tuntutan sesuai wilayah tertentu yang senantiasa berubah. Pendidikan Pancasila dan Kewarganegaraan dalam Kurikulum 2013 menyatakan bahwa Pendidikan Pancasila dan Kewarganegaraan dapat dimaknai sebagai wahana untuk mengem-bangkan dan melestarikan nilai luhur dan moral yang berakar pada budaya bangsa Indonesia yang diharapkan dapat diwujud-kan dalam bentuk perilaku kehidupan sehari-hari peserta didik baik sebagai individu, maupun sebagai anggota masyarakat dalam kehidupan berbangsa dan bernegara.

Mata pelajaran Pendidikan Pancasila dan Kewarganegaraan terkadang dianggap sebagai mata pelajaran yang membosankan dan tidak menarik oleh siswa. Hal ini terjadi karena di karenakan dalam pelaksanaan kegiatan belajar mengajar guru hanya menggunakan metode klasik seperti metode ceramah dan mencatat belum lagi guru yang tidak dapat menyesuaikan kondisi siswa engan materi pembelajaran. Disisi lain juga selain permasalahan dari guru, kebanyakan siswa mengaggap mata pelajaran Pendidikan Pancasila dan Kewarganegaraan ini merupakan mata pelajaran yang membosan-kan karena tidak adanya inovasi belajar yang dibuat oleh guru serta kurangnya pengetahuan guru tentang strategi dan model pembelajaran serta kurangnya pemanfaatan media dalam proses pembelajaran yang menunjang pembelajar-an tersebut, sehingga siswa tidak bisa menumbuhkan kreatifitasnya. Selain itu, pakar lainnya menemukan bahwa kepribadian peserta didik belum terbina dengan baik, karakter keindonesiaan belum memenuhi standar pendidikan, pengetahuan tentang konsep-konsep Pendidikan Pancasila dan Kewarganegaraan masih kurang, penggunaan media yang digunakan oleh guru masih kurang tidak variatif, fasilitas pendukung pembelajaran belum efektif penggunaannya sehingga berdampak pada minimnya kompetensi siswa, berbagai masalah tersebut menyebabkan tidak meningkatkan pengetahuan siswa dalam proses pembelajaran[2]. Siswa kurang berminat pada mata pelajaran PKn karena guru tidak menerapkan model pembelajaran yang bervariasi namun mereka hanya selalu mengajar secara monoton satu konsep pembelajaran berupa ceramah sehingga berdampak pada prestasi siswa itu sendiri tidak meningkat. Selain itu, faktor yang mempengaruhi hasil belajar siswa disebabkan faktor internal dan eksternal[3].

Penggunaan model pembelajaran yang konvensional dan ceramah yang mengakibatkan siswa hanya mendengarkan guru menyampaikan materi, siswa cenderung diam dan tidak aktif terhadap proses pembelajaran yang sedang berlangsung. Pengajaran yang seperti demikian di atas menginstruksikan bahwa perlu dilakukannya berbagai cara mengajar lain yang membuat siswa lebih aktif dengan didukung oleh adanya model pembelajaran yang tepat dan sesuai dengan karakter siswa.

Banyak cara yang dapat dilakukan untuk mencapai pembelajaran yang dinamis dan memberikan perubahan cara belajar pada siswa sehingga proses pembelajaran tidak hanya terpaku pada guru tapi siswa dituntut untuk aktif didalamnya salah satu caranya adalah guru menerapkan pembelajaran cooperative learning. Pembelajaran cooperative learning meng-upayakan peserta didik mampu mengajarkan kepada peserta lain, memberikan peserta didik mempelajari sesuatu dengan baik pada waktu yang bersamaan maka menjadi sumber bagi teman yang lain. Tugas-tugas belajar yang kompleks seperti pemecahan masalah, berpikir kritis, berpikir konseptual, meningkatkan secara nyata pada saat digunakan pembelajaran cooperative learning.

Salah satu model dari pembelajaran cooperative learning adalah model pembelajaran Numbered Head Together (NHT). Model pembelajaran ini merupakan model pembelajaran yang mengedepankan kepada aktivitas siswa dalam mencari, mengelola, dan meaporkan informasi dari berbagai sumber yang ahirnya dipresentasikan di depan kelas[4]. Model Numbered Heads Together (NHT) adalah salah satu jenis pembelajaran kooperatif yang menekankan struktur khusus yang dirancang untuk mempengaruhi pola interaksi siswa dan memiliki tujuan untuk meningkatkan penguasaan siswa. NHT banyak melibatkatkan siswa dalam meninjau materi yang dibahas dalam pelajaran dan memeriksa pemahaman siswa tentang isi pelajaran[5].

Temuan lainnya menjelaskan bahwa 1) NHT berpotensi 72,45\% lebih untuk meningkatkan prestasi kognitif daripada model pembelajaran konvensional. 2) Prestasi kognitif siswa kemampuan akademik tinggi adalah 30,03\% berbeda dibandingkan dengan siswa berkemampuan akademik rendah. 3) Tidak ada pengaruh interaksi antara model pembelajaran dan kemampuan akademik[6].

Dalam model pembelajaran cooperative learning tipe numbered head together ini guru bertindak sebagai motivator dan fasilitator aktivitas siswa. Model pembelajaran ini juga untuk melatih rasa sosial siswa, kerja sama dan kemampuan member penilaian. Model ini bertujuan untuk meningkatkan kemampuan siswa dalam menuangkan ide, pikiran, pengalaman, dan pendapatnya dengan benar. Dengan model numbereded head together memungkinkan bagi siswa untuk saling bertukar pendapat dan saling memberi saran. Dari uraian di atas, maka dalam tujuan penelitian ini yaitu untuk mengetahui pengaruh model pembelajaran cooperative learning tipe numbered head together (NHT) terhadap hasil belajar Pendidikan Pancasila dan Kewarganegaraan siswa sekolah menengah pertama. 


\section{B. METODE PENELITIAN}

\section{Jenis Penelitian}

Jenis penelitian yang digunakan dalam penelitian ini adalah penelitian kuantitatif. Penelitian kuantitaif sesuai dengan namanya, banyak dituntut menggunakan angka, mulai dari pengumpulan data, penafsiran terhadap data tersebut, serta penampilan dari hasilnya. Demikian juga pemahaman akan kesimpulan penelitian akan lebih baik apabila disertai dengan tabel, grafik, bagan, gambar atau tampilan lain[7].

Metode penelitian eksperimen adalah metode penelitian yang digunakan untuk mencari pengaruh perlakuan tertentu terhadap yang lain dalam kondisi yang terkendalikan[8]. Penelitian ini merupakan jenis penelitian Pre-Eksperimen dengan desain penelitian yang digunakan adalah One Group Pretest-Posttest Design. Yaitu desain penelitian eksperimen yang dilakukan pada siswa satu kelas saja tanpa kelas pembanding dengan cara memberikan tes awal dan tes ahir terhadap sampel penelitian.

Pada desain One Group Pretest-Posttest dilakukan melalui tiga langkah sebagaimana dijelaskan oleh [9]: pertama; mengukur variabel terikat sebelum perlakuan diberikan (pretst), kedua memberikan perlakuan eksperimen terhadap sampel penelitian, ketiga; mengukur kembali variabel terikat setelah diberikan perlakuan (posttest). Penggunaan desain One Group Pretest-Posttest untuk mengetahui besarnya perbeadaan rata-rata skor sebelum dan sesudah diberikan perlakuan. Dalam hal ini terdapat satu kelompok sampel penelitian yang diberikan tes awal untuk mengetahui kondisi awal sebelum perlakuan (O1) kemudian pada sampel penelitian diberikan tes ahir untuk melihat ada tidaknya akibat yang ditimbulkan dari perlakuan yang diberikan (O2) dengan demikian hasil perlakuan dapat dketahui. Lebih akurat karena dapat membandingkan dengan keadaan sebelum diberikan perlakuan.

Desain eksperimen dalam bentuk Pre-Eksperimen dengan desain One-Group Pretest-Postest.

\section{Keterangan:}

O1 :Perlakuan yang diberikan (metode pembelajaran cooperative learning tipe numbered head together).

O2 : Nilai test setelah diberikan Perlakuan[7].

\section{Populasi dan Sampel Penelitian}

Populasi adalah keseluruhan dari objek penelitian yang mempunyai karakteristik tertentu dalam penelitian. Dalam penelitian ini yang menjadi populasi adalah siswa-siswi kelas VIII di MTs Al-Madaniyah Mataram tahun ajaran 2017/2018 yang terdiri dari 2 (dua) kelas dengan jumlah keseluruhan siswa sebanyak 57 orang. Untuk lebih jelas tentang populasi penilitian dapat dilihat pada tabel dibawah ini.
Tabel 1

Keadaan Populasi Penelitian Kelas VIII di MTs AlMadaniyah Mataram

\begin{tabular}{ll}
\hline \multicolumn{1}{c}{ Kelas } & Jumlah siswa \\
\hline VIII A & 33 Orang \\
VIII B & 24 Orang \\
\hline
\end{tabular}

Untuk pengambilan sampel penelitian, peneliti melakukan pengambilan sampel dengan menggunakan teknik simple random sampling yaitu pengambilan anggota sampel dari populasi dilakukan secara acak tanpa memperhatikan strata yang ada di dalam populasi itu. Teknik ini dilakukan jika populasinya homogen. Sampel yang akan digunakan dalam penelitian ini terdiri dari 1 kelas yaitu kelas VIIIB yang kemudian dibagi menjadi 2 kelompok yaitu kelompok eksperi-men dan kelompok kontrol.

\section{Teknik Pengumpulan Data}

Teknik pengumpulan data yang peneliti gunakan adalah observasi, tes, dan dokumentasi. Menurut Hadi dalam [10] observasi merupakan suatu proses kompleks, suatu proses yang tersusun dari berbagai proses biologis dan psikologis. Tes sendiri menurut [7] mengemukakan bahwa tes adalah serentetan pertanyaan atau latihan serta alat dan lainnya yang digunakan untuk mengukur keterampilan pengetahuan intelegensi, kemampuan atau bakat yang dimiliki oleh individu atau kelompok. Teknik tes digunakan untuk mengumpulkan data bersifat kuantitatif (angka) berupa nilainilai hasil belajar siswa pada ranah kognitif, tes dalam penelitian ini digunakan untuk mengetahui sejauh mana tingkat pengetahuan siswa dalam pembelajaran PPKn. Tes dilaksanakan pada awal pembelajaran sebelum siswa mendapatkan materi (pretest) dan di akhir pembelajaran setelah siswa mendapatkan materi (posttest).

Dokumen merupakan catatan peristiwa yang sudah berlalu. Dokumen bisa berbentuk tulisan, gambar, atau karya-karya monumental dari seseorang. Dokumen yang berbentuk tulisan misalnya catatan harian, sejarah kehidupan, cerita, biografi, peraturan dan kebijakan. Dokumen yang berbentuk gambar misalnya foto, sketsa dan lain-lain, sedangkan dokumen yang berbentuk karya misalnya karya seni yang dapat berupa gambar, patung, film dan lain-lain[10]. Adapun dokumen yang diperlukan dalam penelitian ini adalah gamabaran umum lokasi penelitian, keadaan sekolah, guru, siswa, struktur organisasi dan lain-lain.

\section{Instrumen Penelitian}

Instrument adalah alat pada waktu penelitian dengan menggunakan sesuatu metode[7]. Sedangkan pendapat lain mengatakan instrumen penelitian adalah alat bantu yang dipilih dan digunakan peneliti dalam kegiatan pengumpulan data[11]. 
Berdasarkan kedua pendapat di atas dapat disimpulkan instrument penelitian adalah sebuah alat yang digunakan oleh para peneliti untuk mendapatkan data. Adapun in strument yang digunakan dalam penelitian ini, yaitu:

a. Instrumen Tes

Dalam penelitian ini tes dilakukan untuk mengetahui hasil belajar siswa dengan menggunakan model pembelajaran cooperative learning type numbered head together. Soal tes diambil dari buku paket PPKn yang sesuai dengan materi yang telah diampaikan pada proses pembelajaran. Tes ini dilakukan dalam bentuk tes objektif (pilihan ganda) yang terdiri dari 10 soal. Masing-masing soal terdiri dari 5 alternatif pilihan jawaban yaitu a, b, c, d, dan e dengan ketentuan apabila siswa menjawab dengan benar mendapat skor 0 . Instrumen tes digunakan dua kali, yaitu sebagai pretest untuk mengetahui kemampuan kemampuan awal siswa dengan menggunakan materi PPKn dan posttest untuk mengetahui hasil belajar siswa.

1) Uji Validitas

Validitas adalah ukuran yang mennunjukkan tingkat-tingkat kevalidan atau kesahihan suatu instrumen. Suatu instrumen yang valid atau sahih mempunyai validitas tinggi. Sebuah instrumen dikatakan valid apabila dapat mengungkap data dari variabel yang diteliti secara tepat. Tinggi rendahnya validitas instrumen menunjukkan sejauh mana data yang terkumpul tidak menyimpang dari gambaran tentang validitas yang dimaksud (Arikunto, 2006: 168). Rumus yang digunakan untuk mencari validitas instrumen tes adalah rumus koefisien kerelasi biserial, yaitu:

$$
\mathrm{r}_{\mathrm{pbi}}=\frac{\mathrm{Mp}-\mathrm{Mt}}{\mathrm{SDt}} \sqrt{\mathrm{Q}}
$$

Keterangan:

Rpbi : Angka indeks korelasi biserial

Mp : Mean Skor dari subjek yang menjawab benar

Mt : Mean skor total (skor rata-rata dari seluruh pengikut tes).

SDt: standar deviasi dari skor total.

$\mathrm{P} \quad$ : Proporsi siswa yang menjawab benar.

$\mathrm{q}$ : Proporsi siswa yang menjawab salah $(\mathrm{q}=1-\mathrm{p})[7]$

Hasil uji validitas item menunjukkan bahwa dari 20 soal diperoleh 20 item soal yang valid. Hasil uji validitas dapat dilihat pada Tabel 3.1.

Tabel 2

Data Hasil Uji Validitas

\begin{tabular}{llll}
\hline $\begin{array}{l}\text { No. } \\
\text { Soal }\end{array}$ & $\begin{array}{l}\text { Nilai } \\
\text { rhitung }\end{array}$ & $\begin{array}{l}\text { Nilai } \\
\text { rtabel }\end{array}$ & Keterangan \\
\hline 1 & 0.470 & 0.355 & Valid \\
2 & 0.490 & 0.355 & Valid \\
3 & 0.496 & 0.355 & Valid \\
4 & 0.551 & 0.355 & Valid \\
\hline
\end{tabular}

\begin{tabular}{cccl}
\hline 5 & 0.439 & 0.355 & Valid \\
6 & 0.583 & 0.355 & Valid \\
7 & 0.497 & 0.355 & Valid \\
8 & 0.401 & 0.355 & Valid \\
9 & 0.484 & 0.355 & Valid \\
10 & 0.813 & 0.355 & Valid \\
11 & 3.448 & 0.355 & Valid \\
12 & 0.430 & 0.355 & Valid \\
13 & 0.444 & 0.355 & Valid \\
14 & 0.410 & 0.355 & Valid \\
15 & 0.457 & 0.355 & Valid \\
16 & 0.526 & 0.355 & Valid \\
17 & 0.557 & 0.355 & Valid \\
18 & 0.409 & 0.355 & Valid \\
19 & 0.437 & 0.355 & Valid \\
20 & 0.443 & 0.355 & Valid \\
\hline kan & \multicolumn{3}{c}{ Tabel 4.1 di atas untuk $\mathrm{n}=20$}
\end{tabular}

Berdasarkan Tabel 4.1 di atas untuk $\mathrm{n}=20$ besarnya rtabel 0,355 dan soal katakan valid jika rhitung $\geq$ rtabel sebaliknya soal dikatakan tidak valid jika rhitung < rtabel.

2) Uji reliabilitas

Reliabilitas adalah derajat ketetapan, ketelitian dan keakuratan yang ditunjukan oleh instrumen. Reliabilitas artinya dapat dipercaya atau dapat diandalkan. Untuk mencari reliabilitas tes dalam penelitian ini menggunakan rumus K-R 20. Adapun rumusnya adalah sebagai berikut :

$$
\begin{aligned}
& \mathrm{r}_{11}=\left(\frac{K}{k-1}\right)\left(\frac{V t-\sum p q}{V t}\right) \\
& \text { Keterangan: } \\
& =\text { reliabilitasas } \\
& \mathrm{r}_{11} \quad \text { instrument } \\
& \text { R11 = reliabilitas instrumen } \\
& \mathrm{k} \text { = banyaknya butir pertanyaan } \\
& \mathrm{V} 1 \text { = varians total } \\
& \mathrm{P}=\text { proporsi subjek yang menjawab } \\
& \text { butir dengan betul (proporsi subjek } \\
& \text { yang mempunyai skor 1) } \\
& q=\text { proporsi subjek yang mendapat skor } \\
& \text { o }(\mathrm{q}=1-\mathrm{p})[7]
\end{aligned}
$$

Setelah diperoleh nilai dari $\mathrm{r}_{11}$ kemudian dikonsultasikan dengan batas kepercayaan jika nilai $\mathrm{r}_{11}>$ dari $\mathrm{r}$ table maka soal tersebut dinyatakan reliabel dan jika $\mathrm{r}_{11}<$ dari $\mathrm{r}$ table maka soal tersebut tidak reliabel.

Hasil perhitungan reliabilitas dengan menggunakan rumus KR 20 diperoleh hasil sebesar 0,782 , dimana $\mathrm{n}=20$ besarnya $\mathrm{r}_{\text {tabel }} 0,355$, karena nilai $\mathrm{r}_{\text {hitung }}>\mathrm{r}_{\text {tabel }}$ maka soal tersebut reliabel.

\section{Identifikasi dan Definisi Operasional Variabel}

1) Identifikasi variabel 
Dalam penelitian ini terdapat dua variabel yaitu variabel bebas dan variabel terikat. Adapun pengertian dari kedua variabel tersebut adalah:

a) Variabel bebas (variable independent) yaitu vartiabel yang mempengaruhi atau yang menjadi sebab perubahan dan timbulnya variabel terikat. Variabel bebas dalam penelitian ini adalah model pembelajaran cooperative learning tipe numbered head together.

b) Variabel terikat, yaitu variabel terikat (variable dependent ) yaitu varibel yang di pengaruhi atau menjadi akibat karena adanya variabel bebas[10]. Adapun yang menjadi variabel terikatnya adalah Hasil belajar siswa.

2) Definisi operasional variabel

Untuk menghindari penafsiran yang berbeda terhadap beberapa istilah yang digunakan dalam penelitian ini, maka perlu dijelaskan definisi operasionalnya. Model pembelajaran Numbered Head Together (NHT). Merupakan salah satu tipe dari pembelajaran kooperatif dengan sintaks: pengarahan, membuat kelompok heterogen dan setiap peserta didik memiliki nomor tertentu, memberikan persoalan materi bahan ajar (untuk tiap kelompok sama tapi untuk tiap siswa tidak sama sesuai dengan nomor siswa, tiap siswa dengan nomor sama mendapat tugas yang sama) kemudian bekerja secara kelompok, melakukan presentasi kelompok dengan nomor siswa yang sama sesuai tugas masing-masing sehingga terjadi diskusi kelas, kuis individual dan buat skor perkembangan tiap siswa, umumkan hasil kuis lalu diberikan penghargaan kelompok.

3) Hasil belajar

Hasil belajar adalah pola-pola perbuatan, nilai-nilai, pengertian-pengertian, sikap-sikap, apresiasi dan keterampilan. Selain itu hasil belajar merupakan hasil proses belajar akibat dari kegiatan belajar yang telah dilakukan oleh individu.

Adapun maksud dari hasil belajar pada mata pelajaran PPKn pada penelitian ini yaitu hasil belajar yang dicapai oleh siswa dalam belajar pada salah satu pokok bahasan mata pelajaran PPKn menggunakan model pembelajaran kooperatif learning tipe numbered head together. Hasil belajar yang dicapai oleh siswa didapat dari hasil tes yang diberikan oleh guru.

\section{Metode Analisis Data}

\section{a. Uji prasyarat analisis}

Uji prasyarat analisis adalah adalah cara yang digunakan untuk mengetahui apakah data dari masing-masing variable berdistribusi normal atau tidak, terutama untuk data yang berskala interval dan ratio. Adapun uji prasyarat analisis data dalam penilitian ini adalah sebagai berikut:

1) Uji Normalitas

Uji normalitas dalam penelitian ini di maksudkan untuk mengetahui apakah data itu berdistribusi normal atau tidak. Jika berdistribusi normal maka proses selanjutnya dalam penghitungan hipotesis dapat menggunakan perhitungan statistik parametrik dengan menggunakan uji Chi-kuadrat. Berikut tehnik untuk menguji normalitas distribusi data dengan uji Chi kuadrat:

2) Uji Homogenitas

Pengujian prasyarat analisis yang kedua adalah uji homogenitas, yaitu pengujian mengenai sama tidaknya variasi-variasi dua buah distribusi. Pengujian homogenitas varian menggunakan uji F.

3) Uji hipotesis

Hipotesis dibuktikan dengan menggunakan uji tes "t" atau " $t$ " Test setelah sebelumnya dipenuhi persyaratannya, yaitu uji normalitas dan homogenitas. Teknik yang digunakan untuk menghitung pengaruh model pembelajaran cooperative learning tipe numbered head together Rumus t test adalah sebagai berikut:

$$
\mathrm{t} \text { hitung }=\frac{x_{a}-x_{b}}{\sqrt{\left.\left.\frac{(n-1) s_{1}^{2}+\left(n_{2}-1\right) s_{2}\left(\frac{1}{n_{1}+n_{2}-2}+\left.\frac{1}{n}\right|_{2}\right)}{1}\right)_{2}\right)}}
$$

Keterangan :

$$
\begin{aligned}
& \frac{\mathrm{t}}{\mathrm{X}}=\quad \text { Nilai } \mathrm{t} \text { yang di hitung } \\
& \overline{X_{1}}=\text { Nilai rata-rata sebelum } \\
& \text { diberikan perlakuan. } \\
& \overline{\mathrm{X}_{2}}=\text { Nilai rata-rata sesudah } \\
& 2 \text { diberikan perlakuan } \\
& \mathrm{S}_{1}^{2}=\text { Varians } \\
& \mathrm{S}_{2}{ }_{2}=\text { Varians } \\
& \mathrm{N}_{1}=\text { Jumlah kelompok } \\
& \text { sebelum di berikan } \\
& \text { perlakuan } \\
& \mathrm{N}_{2}=\text { Jumlah kelompok } \\
& \text { sebelum di berikan } \\
& \text { perlakuan }
\end{aligned}
$$

Pengambilan keputusan dalam uji hipotesis ini adalah jika $t_{\text {hitung }}>t_{\text {table }}$ maka kepu tusanya $\mathrm{Ha}$ diterima dan Ho ditolak, sebaliknya jika $t_{\text {hitung }}<t_{\text {tabel }}$ maka keputusannya Ho diterima dan Ha ditolak

\section{HASIL DAN PEMBAHASAN}

Secara umum, hasil penelitian ini telah membuktikan hipotesis yang diajukan, yaitu terdapat pengaruh pembelajaran kooperatif tipe numbered head together terhadap hasil belajar PPKn pokok bahasan nilai-nilai Pancasila pada siswa kelas VIII MTs Al- 
Madaniyah Mataram Tahun Pelajaran 2017/2018. Sebelum melakukan uji hipotesis terlebih dahulu melakukan uji analisis data yaitu terlebih dahulu melakukan uji normalitas data hasil belajar kelas eksperimen dilakukan dengan cara membandingkan hasil $x^{2}$ hitung dengan $x^{2}$ table pada taraf signifikan $5 \%$. Maka distribusi data dapat dinyatakan terdistribusi normal. Dengan demikian kedua kelas dapat dinyatakan terdistribusi normal. Untuk uji homogenitas berdasarkan hasil perhitungan uji homogenitas dapat dikatakan homogen Jadi berdasarkan criteria yang ada, jika $t_{\text {hitung }}<t_{\text {tabel }}$ maka kelas dapat dikatakan memiliki varians yang sama, yang menandakan kedua kelas homogen pada taraf signifikan $5 \%$.

Sesuai hasil penelitian yang diperoleh dari analisis data dan pengujian hipotesis yang telah menunjukkan bahwa terdapat pengaruh pembelajaran kooperatif tipe numbered head together terhadap hasil belajar PPKn pokok bahasan nilai-nilai Pancasila pada siswa kelas VIII MTs Al-Madaniyah Mataram Tahun Pelajaran 2017/2018. Perbedaan yang signifikan ini terlihat dari analisis uji hipotesis yang telah dilakukan dengan menggunakan uji-t. Hasil analisis menunjukkan bahwa hasil uji t diperoleh thitung $=3,523$. Hasil uji $t$ tersebut kemudian dikonsultasikan pada $t_{\text {tabel. }}$ Dengan taraf signifikan $5 \%$ dan $\mathrm{db}=24$ diperoleh tabel $=1,998$, karena $t_{\text {hitung }} \geq \mathrm{t}_{\text {tabel }}$, maka Hipotesis Ha diterima, dengan demikian terdapat pengaruh pembelajaran kooperatif tipe numbered head together terhadap hasil belajar PPKn pokok bahasan nilai-nilai Pancasila pada siswa kelas VIII B MTs Al-Madaniyah Mataram Tahun Pelajaran 2017/2018.

Hasil observasi proses belajar siswa selama proses pembelajaran berlangsung dapat dilihat bahwa proses belajar siswa dengan Penerapan Model pembelajaran cooperative learning tipe numbered head together (NHT) sangat baik. Data hasil observasi kegiatan belajar siswa, memperlihatkan bahwa penyampaian tujuan dan memotivasi, aktivitas pembelajaran serta tanggapan terhadap pemberian penghargaan dengan kategori baik. Sementara itu, kegiatan belajar siswa dalam memperhatikan penyampaian materi, keseriusan dan kesungguhan mengerjakan tes dengan kategori sangat baik. Kegaiatan mengajar guru dalam menyampaikan tujuan dan memotivasi serta membimbing siswa dikategori-kan baik dan kegiatan mengajar guru dalam menyajikan informasi, memperhatikan proses belajar siswa, melakukan evaluasi dan memberikan penghargaan dikategorikan sangat baik.

\section{TEMUAN DAN DISKUSI}

Penerapan model pembelajaran cooperative learning tipe numbered head together (NHT) tampak bahwa siswa kreatif dan memahami apa yang dijelaskan oleh guru dan siswa lebih siap mengerjakan soal latihan yang diberikan oleh guru. Dalam proses belajar mengajar, model mengajar merupakan hal yang terpenting, sebab model mengajar merupakan faktor penunjang dalam menyampaikan materi pelajaran yang akan mampu meningkatkan hasil belajar. Setiap model mengajar mempunyai kelemahan dan kelebihan serta daya cocok yang berbeda bagi setiap siswa.

Penerapan Model pembelajaran cooperative learning tipe numbered head together (NHT) memberikan peluang yang lebih besar untuk peningkatan hasil belajar PPKn siswa khususnya pada pada materi Pembentukan Bumi. Sebab dengan penerapan Model pembelajaran cooperative learning tipe numbered head together (NHT), peserta didik akan dapat memiliki keterampilan dalam menyelesaikan permasalahan yang memuat tentang Pembentukan Bumi. Hal ini sesuai dengan ungkapan [12] bahwa penerapan Model pembelajaran cooperative learning tipe numbered head together (NHT), siswa akan memiliki pengalaman belajar yang berbeda dan bervariasi mengenai suatu konsep atau topik dalam suasana yang menyenangkan sehingga lebih merangsang minat peserta didik untuk belajar sehingga siswa akan lebih termotivasi dalam belajarnya. Sejalan juga dengan pendapat menjelaskan bahwa adanya perbaikan pembelajaran dengan menggunakan model pembelajaran kooperatif tipe Numbered Head Together (NHT) dapat meningkatkan Hasil belajar siswa pada pembelajaran PKn[13].

Peningkatan yang diperoleh dari hasil kegiatan belajar mengajar disebabkan oleh beberapa hal antara lain siswa telah terbiasa dalam proses belajar mengajar yang menggunakan strategi pemecahan masalah sehingga ada perasaan tertarik dan sungguh-sungguh dalam mengikuti proses belajar mengajar. Begitu juga pada proses diskusi atau tanya jawab terjadi komunikasi yang baik antara guru dan siswa tentang materi yang disampaikan. Hal ini berpengaruh terhadap hasil ketuntasan yang diperoleh siswa. Didukung juga sesua hasil penelitian menunjukkan menggunakan model kooperatif tipe Numbered Head Together berbantuan media visual dapat meningkatkan kualitas pembelajaran PKn[14]. Bahwa penggunaan model kooperatif tipe NHT dengan tahapan penomoran, mengajukan pertanyaan, berpikir bersama, dan menjawab pertanyaan memberikan pengaruh yang positif terhadap hasil belajar siswa dengan adanya peningkatan hasil belajar setelah diajar dengan model kooperatif tipe NHT pada pembelajaran PKn[15].

Berbeda dengan model pembelajaran konvensioanal yang dimana siswa hanya membaca, menulis, dan mendengarkan. Sehingga kegiatan belajar siswa hanya terpacu pada mebaca, menulis, dan mendengarkan saja. Kegiatan proses belajar mengajar lebih berpusat pada guru dan pada buku pegangan siswa sehingga komunikasi satu arah dari guru kepada siswa kurang. sedang siswa hanya membaca, menulis, dan mendengarkan apa yang disampaikan guru sehingga 
cenderung meminimalkan keterlibatan siswa serta guru nampak lebih aktif atau dan belum menerapkan model pembelajaran yang inovatif. Namun tidak selamanya model pembelajaran kooperatif tipe Numbered Head Together memiliki nilai positif ada juga nilai negative seperti membutuhkan waktu lama jika siswanya melebihan kapasitas dan hasil sebagian yang aktif.

\section{E. KESIMPULAN DAN SARAN}

Hasil penelitian menunjukkan bahwa terdapat pengaruh pembelajaran kooperatif tipe numbered head together terhadap hasil belajar PPKn pokok bahasan nilai-nilai Pancasila pada siswa kelas VIII MTs AlMadaniyah Mataram Tahun Pelajaran 2017/2018. Hal ini bisa dilihat dari nilai rata-rata pre test yaitu 65 dan post test yaitu 78 .

Berdasarkan hasil perhitungan uji hipotesis dengan menggunkan rumus uji-tes, maka diperoleh $t_{\text {hitung }}$ sebesar 3,523 sedangkan nilai $t_{\text {tabel }}$ pada taraf signifikan $5 \%$ dengan $\mathrm{dk}=n_{1}+n_{2}-2=21+21-2=$ 40 diperoleh harga $t_{\text {tabel }}$ sebesar 1,998. Jadi dari hasil perhitungan dapat disimpulkan $t_{\text {hitung }}>t_{\text {tabel }}$.

Hasil pengujian $t_{\text {hitung }}>t_{\text {tabel }}$, maka dapat dikatakan hipotesis (Ha) diterima. Ini berarti bahwa "terdapat pengaruh pembelajaran kooperatif tipe numbered head together terhadap hasil belajar PPKn pokok bahasan nilai-nilai Pancasila pada siswa kelas VIII MTs Al-Madaniyah Mataram Tahun Pelajaran 2017/2018”. Diterima. pinjaman, kreditan, 4. Anggaran yang minim menghambat pengembangan program BUMDes.

Dengan demikian disarakan guru sebagai rujukan bagi guru yang ingin menenerapkan pembelajaran yang tepat dalam proses belajar mengajar dalam pendidikan PPKn serta sekolah dapat memberikan konstribusi yang baik dalam rangka perbaikan pembelajaran di sekolah khususnya pembelajaran pendidikan PPKn.

\section{UCAPAN TERIMA KASIH}

Penulis mengucapkan terima kasih kepada LPPM UM Mataram dan MTs Al-Madaniayh Mataram yang senantiasa memberikan dukungan dana dan kegiatan proses penelitian kepada penulis sehingga artikel ilmiah ini selesai dengan tepat waktu.

\section{DAFTAR RUJUKAN}

[1] D. Wahyudin, "Pengantar Pendidikan," Jakarta Univ. Terbuka, 2007.

[2] A. Sakban and S. Nirwana, "Pelaksanaan PDS Model Problem Based Learning Untuk Meningkatkan Pengetahuan Siswa pada Mata Pelajaran PPKn di Kelas VII SMPN 2 Labuapi Lombok Barat," in Prosiding Seminar Nasional II APPPI NTB 2018, 2018, vol. 1, no. 1.

[3] A. Sakban and K. Aini, "Penerapan Model
Pembelajaran Concept Mapping Untuk Meningkatkan Motivasi dan Prestasi Belajar PKn Pada Siswa Kelas V MI NW Apitaik Lombok Timur Tahun Pelajaran 2015/2016," Civ. Pendidikan-Penelitian-Pengabdian Pendidik. Pancasila dan Kewarganegaraan, vol. 4, no. 1, pp. 123-128, 2016.

[4] J. Susanto, "Pengembangan Perangkat Pembelajaran Berbasis Lesson Study dengan Kooperatif Tipe Numbered Heads Together untuk Meningkatkan Aktivitas dan Hasil Belajar IPA di SD," J. Prim. Educ., vol. 1, no. 2, 2012.

[5] R. Lince, "Creative thinking ability to increase student mathematical of junior high school by applying models numbered heads together.," $J$. Educ. Pract., vol. 7, no. 6, pp. 206-212, 2016.

[6] M. Leasa and A. D. Corebima, "The effect of numbered heads together (NHT) cooperative learning model on the cognitive achievement of students with different academic ability," in Journal of Physics: Conference Series, 2017, vol. 795, no. 1, p. 12071.

[7] A. Suharsimi, "Prosedur penelitian suatu pendekatan praktik," Jakarta: Rineka Cipta, 2006.

[8] Sugiyono, Metode Penelitian Pendidikan:(Pendekatan Kuantitatif, Kualitatif dan $R \&$ \&). Alfabeta, 2014.

[9] N. Sudjana, "Penelitian Hasil Belajar Mengajar," Bandung: Rosdakarya, 2005.

[10] Sugiyono, "Metode Penelitian kuantitatif kualitatif dan R dan D," Alf. Bandung, 2010.

[11] A. Mardalis, "Implementasi 12 Pilar Pemasaran untuk Promosi Pendidikan Tinggi," 2014.

[12] F. L. N. Isjoni, "Pembelajaran Terkini Perpaduan Indonesia-Melayu.” Yogyakarta, Pustaka Pelajar, 2007.

[13] I. W. Suwastana, "Penerapan Pembelajaran Melalui Model Kooperatif Numbered Heads Together Siswa Kelas V SDN No 1 Tonggolobibi Untuk Meningkatkan Prestasi Belajar PKn," $J$. Kreat. Tadulako, vol. 4, no. 1, 2016.

[14] P. D. Wijanarko and P. Sukarjo, "Numbered Head Together Berbantuan Media Visual Untuk Meningkatkan Kualitas Pembelajaran PKn,” Joyf. Learn. J., vol. 3, no. 1, 2014.

[15] J. Hidayat and A. Salimi, "Pengaruh Model Numbered Head Together Terhadap Hasil Belajar Pendidikan Kewarganegaraan Di Sekolah Dasar," J. Pendidik. dan Pembelajaran, vol. 4, no. 10, 2018. 